\title{
Specific epibacterial communities on macroalgae: phylogeny matters more than habitat
}

\author{
Tim Lachnit*, Martina Blümel, Johannes F. Imhoff, Martin Wahl \\ Leibniz Institute of Marine Sciences (IFM-GEOMAR), Düsternbrooker Weg 20, 24105 Kiel, Germany
}

\begin{abstract}
Epibacterial communities on thalli of the algal species Fucus serratus, Fucus vesiculosus, Laminaria saccharina, Ulva compressa, Delesseria sanguinea and Phycodrys rubens were analysed using 16S ribosomal RNA gene-based DGGE. Individuals of all species were collected in the Kiel Fjord (Baltic Sea) and in the rocky intertidal of Helgoland (North Sea). DGGE gels as well as cluster and multidimensional scaling analysis based on the DGGE band patterns of the epibacterial community showed significant differences between the epibacterial communities on the investigated algal species both in the Baltic and North Seas. Epibacterial communities differed less between regions than between host species, and were more similar on closely related host species. Results give the first evidence for lineage-specific bacterial associations to algal thalli. Furthermore, the results suggest that these algal species may control their epibiotic bacterial communities.
\end{abstract}

KEY WORDS: Biofilm · Bacteria $\cdot$ Antifouling $\cdot$ Algae $\cdot$ DGGE

\section{INTRODUCTION}

The brown algae Fucus serratus, F. vesiculosus and Laminaria saccharina, the green alga Ulva compressa and the red algae Delesseria sanguinea and Phycodrys rubens are common representatives of macroalgae in the Baltic and North Seas. Most aquatic organisms, in particular primary producers like macroalgae, interact with their biotic and abiotic environment through their surface (Wahl 2008). Functionally relevant features of this interface are colour, texture, flexibility, transparency, permeability, toxicity, smell and taste. All these characteristics are affected when the alga's surface is colonized by epibionts. Epibiosis, the settlement of organisms on living surfaces, is known to dramatically modify the strength and mode of interaction between a host and its environment (Wahl \& Hay 1995, Rohde et al. 2008). After chemical surface conditioning, bacterial colonization is the second of 4 steps of the colonization of a new surface, thus prokaryotes can be regarded as primary colonizers of algal thalli (Wahl 1989). Epibiotic bacteria play a key role in the colonization process of an algal thallus for several reasons: they are fast colonizers, highly adaptive and capable of quick metabolization of algal exudates. Furthermore, under certain circumstances, epibiotic bacteria may serve as a nutrient source for the algae (Croft et al. 2006) and they may supply growth factors for algae (Matsuo et al. 2005, Tsavkelova et al. 2006). Of course, some epibiotic bacteria on algal thalli also are known as pathogens (Michel et al. 2006), e.g. Alteromonas sp. (Vairappan et al. 2001) and Pseudo alteromonas sp. (Ivanova et al. 2002).

However, epibiotic bacteria are also supposed to have a profound effect on further colonization processes (Harder et al. 2002, Tait et al. 2005, Dobretsov et al. 2006). Dobretsov \& Qian (2002) investigated the effect of several bacterial strains on marine micro- and macrofouling on Ulva reticulata and found a Vibrio sp. which significantly inhibits settlement and metamorphosis of polychaete larvae. Their results suggest that certain epibacteria may contribute to the host alga's protection against further fouling. On the other hand, a review on this topic suggests that, depending on the composition, biofilms grown on hard substrate promote larval settlement (Wieczorek \& Todd 1998). In either 
case, the capacity to control its epibacterial community should be of substantial ecological and selective advantage for the individual alga. Because of the different composition of the thalli of brown, red and green algae, it can be assumed that their thallus surfaces are colonized in differing manners (temporal and spatial distribution on the thallus) by bacteria (Longford et al. 2007) and probably host different epibacterial communities on their thalli. For example, several red algae are known to actively control the bacterial colonization on their thalli. Steinberg et al. (1997) showed that Delisea pulchra produces a furanone resembling signal molecules of the acyl homoserine lactone (AHL) regulation system of gram-negative bacteria leading towards a selective enrichment of gram-positive bacteria on thalli of this species. Weinberger et al. (1999) demonstrated another defense mechanism of the red alga Gracilaria conferta: this alga is able to secrete hydrogen superoxide when colonized by agarolytic bacteria.

To date there are few studies dealing with the bacterial community composition of different algal species. Culture-based studies on the bacterial epibionts of Laminaria saccharina revealed a shift from mesophilic bacterial species in summer to psychrophilic bacteria in winter (Mazure \& Field 1980). This may be due to seasonal variation in either the presence of different bacterial strains in the surrounding water or the ability of bacterial species to attach to the algal surface. Staufenberger et al. (2008) recently analysed the bacterial community attached to $L$. saccharina using DGGE and clone libraries based on PCR-amplified 16S ribosomal RNA (rRNA) gene fragments in the North and Baltic Seas. The authors showed that on young algal tissues there was a close correlation between bacterial communities on different conspecific algae, regardless of the sample origin and season.

Based on the results of these different studies it may be assumed that the epibiotic bacterial community may differ between algal species. Therefore, the present study focused on the analysis of epibacterial communities on different algal individuals belonging to red, green and brown macroalgae of the North and Baltic Seas using 16S rRNA gene-based DGGE.

\section{MATERIALS AND METHODS}

Sampling. Three individuals each of 6 marine algal species were collected in August 2004 in the Baltic (Kiel Fjord, 54 $27^{\circ} 4 \mathrm{~N}, 10^{\circ} 12^{\prime} \mathrm{E}$ ) and North Seas (north coast of Helgoland, $54^{\circ} 11^{\prime} 5 \mathrm{~N}, 7^{\circ} 52^{\prime} 5 \mathrm{E}$ ). The sampling site in the Kiel Fjord was located in the littoral zone in an area protected from strong currents, whereas samples in Helgoland (North Sea) were taken in a littoral zone strongly influenced by tidal changes. Salinity in the
North Sea is around $35 \%$, compared to $15 \%$ in the Kiel Fjord. Selected algal species for analysis were Fucus serratus Linnaeus, F. vesiculosus Linnaeus, Laminaria saccharina (Linnaeus) Lamouroux, Ulva compressa, Delesseria sanguinea (Hudson) Lamouroux and Phycodrys rubens (Linnaeus) Batters. These species represent all 3 major macroalgal phyla and were present at both sampling locations during the sampling season. Sampling in the North and Baltic Seas was performed by SCUBA diving. Algal individuals showing a good physiological state were collected individually in sterile Ziploc bags and transported to the laboratory in a cooler $\left(<10^{\circ} \mathrm{C}\right)$. Within $2 \mathrm{~h}$ after collection, the individual algae were washed 10 times (water exchange after each step) in sterile petri dishes with filtered $(0.2 \mu \mathrm{m}$ pore size) and autoclaved seawater to remove loosely attached bacteria. Rinsed samples were placed in empty, sterile petri dishes. Two $\mathrm{cm}^{2}$ of the surface of each algal individual was vigorously swabbed with a sterile cotton-tipped applicator. Only young and clean thallus regions were sampled from $F$. vesiculosus, F. serratus and L. saccharina, whilst swabs of whole algal surfaces were taken from $U$. compressa, D. sanguinea and P. rubens. Subsequently, swab tips were transferred to sterile $2 \mathrm{ml}$ vials and frozen at $-20^{\circ} \mathrm{C}$ until further analysis.

DNA extraction. DNA was extracted using the QiaAmp DNA Mini Kit (Qiagen) following the manufacturer's instructions (buccal swab protocol). For elution, DNA-free water (Fluka Biochemica) was used instead of Buffer AE.

PCR amplification. PCR of 16S rRNA genes of bacterial community DNA was performed using PuReTaq Ready-To-Go PCR Beads (GE Healthcare) in a total PCR volume of $25 \mu \mathrm{l} ; 10 \mathrm{pmol}$ of each bacterial primer 341F-GC (5' - [CGC CCG CCG CGC GCG GCG GGC GGG GCG GGG GCA CGG GGG GCl CTA CGG GAG GCA GCA G-3') and 534R (5'-ATT ACC GCG GCT GCT GG-3') was used for amplification of suitable fragments for DGGE (Muyzer et al. 1993). A GCclamp (sequence in square brackets) was attached to the $5^{\prime}$ end of the forward primer.

PCR conditions were as follows: initial denaturation at $94^{\circ} \mathrm{C}$ for $2 \mathrm{~min} ; 15$ touchdown cycles starting with an annealing temperature of $65^{\circ} \mathrm{C}$ for $40 \mathrm{~s}$ and an incremental reduction of $1^{\circ} \mathrm{C}$ per cycle; elongation at $72^{\circ} \mathrm{C}$ for $40 \mathrm{~s}$; and denaturation at $95^{\circ} \mathrm{C}$ for $30 \mathrm{~s}$. The touchdown steps were followed by 40 cycles of annealing temperature at $50^{\circ} \mathrm{C}$ for $40 \mathrm{~s}$, elongation at $72^{\circ} \mathrm{C}$ for $40 \mathrm{~s}$ and denaturation at $94^{\circ} \mathrm{C}$ for $30 \mathrm{~s}$; a final annealing step was performed at $42^{\circ} \mathrm{C}$ for $60 \mathrm{~s}$ and a final elongation at $72^{\circ} \mathrm{C}$ for $5 \mathrm{~min}$. The correct size of the amplified DNA fragments was verified by electrophoresis of $10 \%$ of the PCR reaction volume in $2 \%$ agarose in $1 \times$ TBE buffer.

DGGE was performed using double gradient polyacrylamide gels (Petri \& Imhoff 2001). DGGE gels 
contained a denaturing gradient from 40 to $80 \%(100 \%$ defined as $7 \mathrm{M}$ urea and $10 \mathrm{M}$ formamide) and an acrylamide (Acrylamide-Bis: $37.5: 1)$ gradient from $6 \%$ to $8 \%$. Electrophoresis was run at $60^{\circ} \mathrm{C}$ for $13.5 \mathrm{~h}$ at $80 \mathrm{~V}$ in $0.5 \times \mathrm{TAE}$ buffer in a CBS Scientific DGGE-2001 system. After electrophoresis, the gel was stained for $45 \mathrm{~min}$ in SYBR Gold ${ }^{\circledR}$ (Invitrogen), rinsed for $30 \mathrm{~min}$ in $1 \times$ TAE buffer and photographed under UV light.

Statistical analysis. DGGE gels were analysed by the generation of a presenceabsence matrix based on the band pattern. All visible bands in every gel lane were taken into account for further calculation using the Primer software v.6.1.9 (Primer-E). To further ensure the comparability of band patterns, only samples from one gel were compared with each other. Bray-Curtis values without transformation were calculated. Sample similarities are shown by cluster analysis and non-metric multidimensional scaling (NMDS). Band positions were assigned to species and the program then compared species composition within and among host alga species using analysis of similarities (ANOSIM). The ANOSIM global test was used for the pairwise comparison of cluster groups. R-values near 1 indicate that similarity within a group is higher than between different groups.

\section{RESULTS}

According to the 16S rRNA gene-based DGGE analysis, the epibacterial community composition differed between algal species in the Baltic Sea. This observation was confirmed by the statistical analysis
Table 1. ANOSIM pairwise comparison of epibacterial communities on different algal phyla from the Baltic and North Seas derived from DGGE band pattern analysis. Algal individuals were arranged according to their phyloof DGGE band pattern of the epibacterial community was analysed within and between group identities. R-values near 1 indicate a higher similarity within a group than between different groups

$\begin{array}{lccccc}\text { Groups } & \mathrm{R} & \begin{array}{c}\text { Significance } \\ \text { level (\%) }\end{array} & \begin{array}{c}\text { Permutations } \\ \text { Possible }\end{array} & \text { Actual } & \text { No. } \\ \text { obs. }\end{array}$

based on the DGGE band pattern. ANOSIM (global test, $\mathrm{R}=0.877, \mathrm{p}=0.001$ ) showed that epibacterial communities on algal thalli differed significantly at the host species level (Table 1).

With only one exception, Ulva individual 1 (U1), the 3 individuals of each species showed a highly similar band pattern (Fig. 1). This result was also reflected in the cluster analysis based on the DGGE band patterns (Fig. 1). In particular, the 3 Delesseria sanguinea individuals showed a high similarity of the epibacterial community (>80\%). Inter-individual similarities were lower in Laminaria saccharina (>50\%) and Phycodrys rubens (>60\%). Interestingly, within the genus Fucus, epibacterial communities were very similar and host species did not differ more than conspecific individuals (Fig. 1). At the other phylogenetic extreme, the epibacterial communities significantly differed between the algal phyla Phaeophyta, Rhodophyta and Chlorophyta according to the results
Fig. 1. DGGE gel and cluster analysis based on 16S rDNA amplified epibacterial communities of 6 macroalgal species from the Baltic Sea (each sampled in triplicate). Cluster analysis of DGGE band patterns was performed using the Bray-Curtis similarity index; similarity values are given in \%. FS: Fucus serratus; FV: Fucus vesiculosus; LS: Laminaria saccharina; U: Ulva compressa; D: Delesseria sanguinea; P: Phycodrys rubens

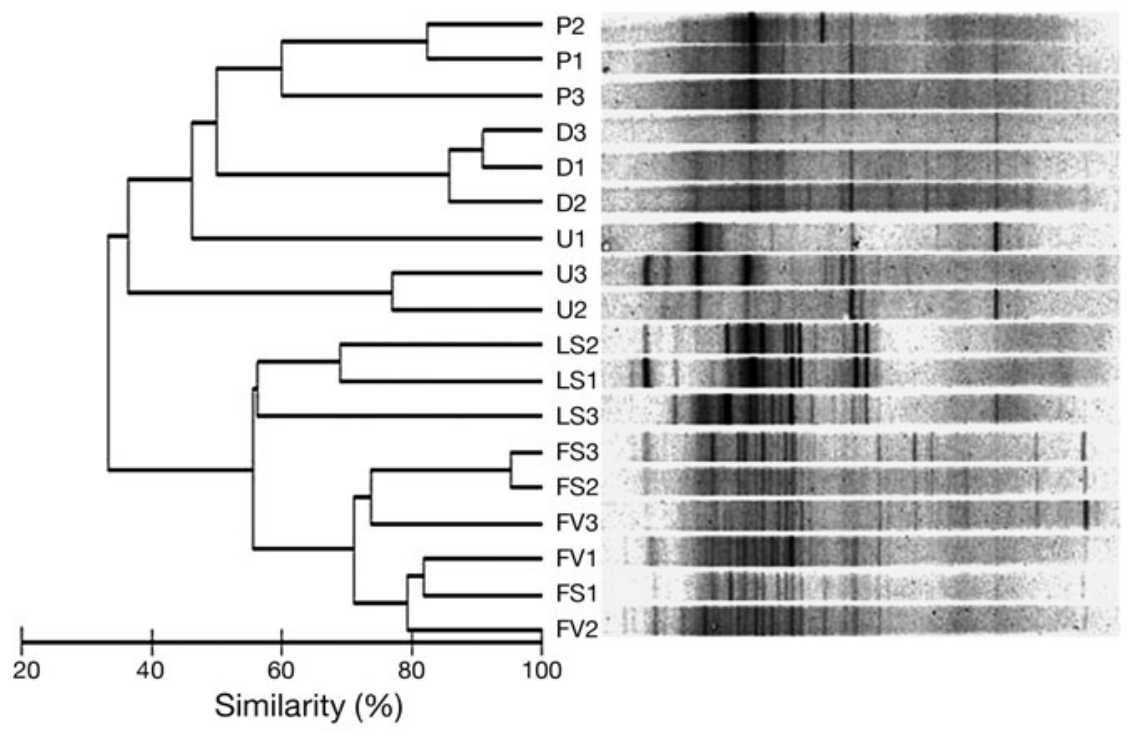


Fig. 2. DGGE gel and cluster analysis based on 16S rDNA amplified epibacterial communities of 6 macroalgal species from the North Sea (each sampled in triplicate). Cluster analysis of DGGE band patterns was performed using the Bray-Curtis similarity index (in \%). Species abbreviations are given in Fig. 1

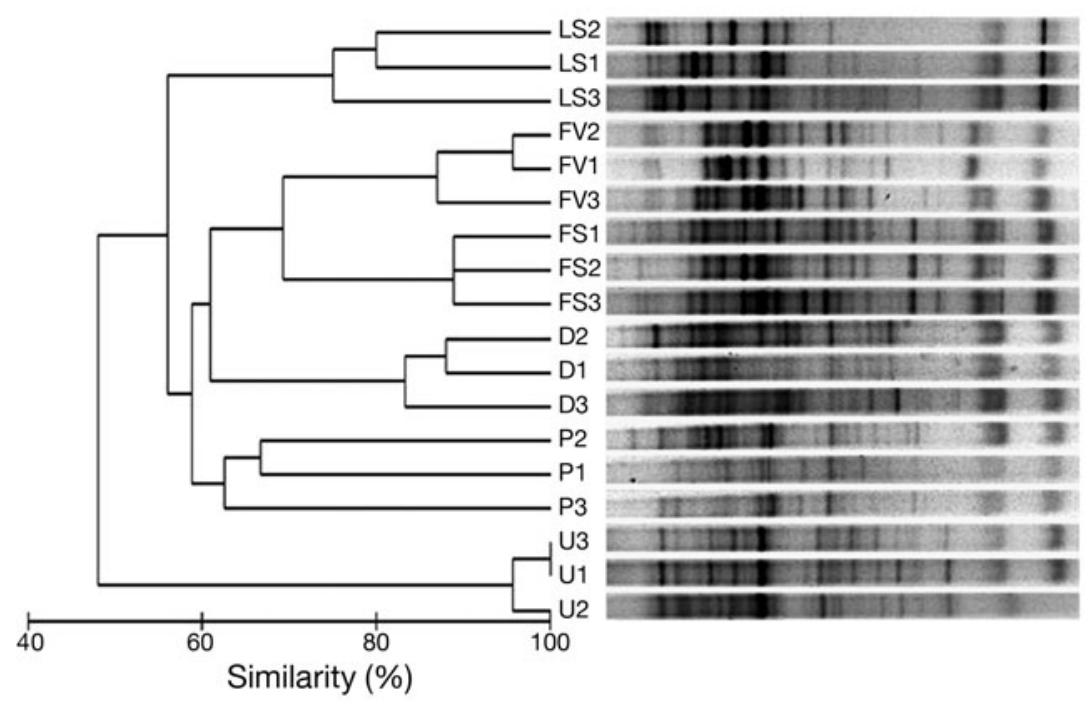

epibiotic communities. Statistical analysis again confirmed that the composition of epibacterial communities differed significantly between host species (ANOSIM global test, $\mathrm{R}=0.981, \mathrm{p}=0.001$ ).

A global comparison of epibacterial communities on the algae originating from the North and Baltic Seas (Fig. 3) showed that bacteria attached to Fucus vesiculosus, Laminaria saccharina, Ulva compressa and Delesseria sanguinea were more similar on conspecific algae from different geographic origins than to other algal species from the same environment. Statistical analysis (Table 2) revealed that the influence of an alga's regional provenance (Baltic or North Sea) on the epibacterial community composition was less important (ANOSIM global test, $\mathrm{R}=-0.033, \mathrm{p}=0.44)$ than the alga's species $(\mathrm{R}=$ $0.892, \mathrm{p}=0.001$ ). Only L. saccharina showed regional difference within conspecific algae $(R=1.0, p=0.01)$. distinctly and all Ulva individuals exhibited similar
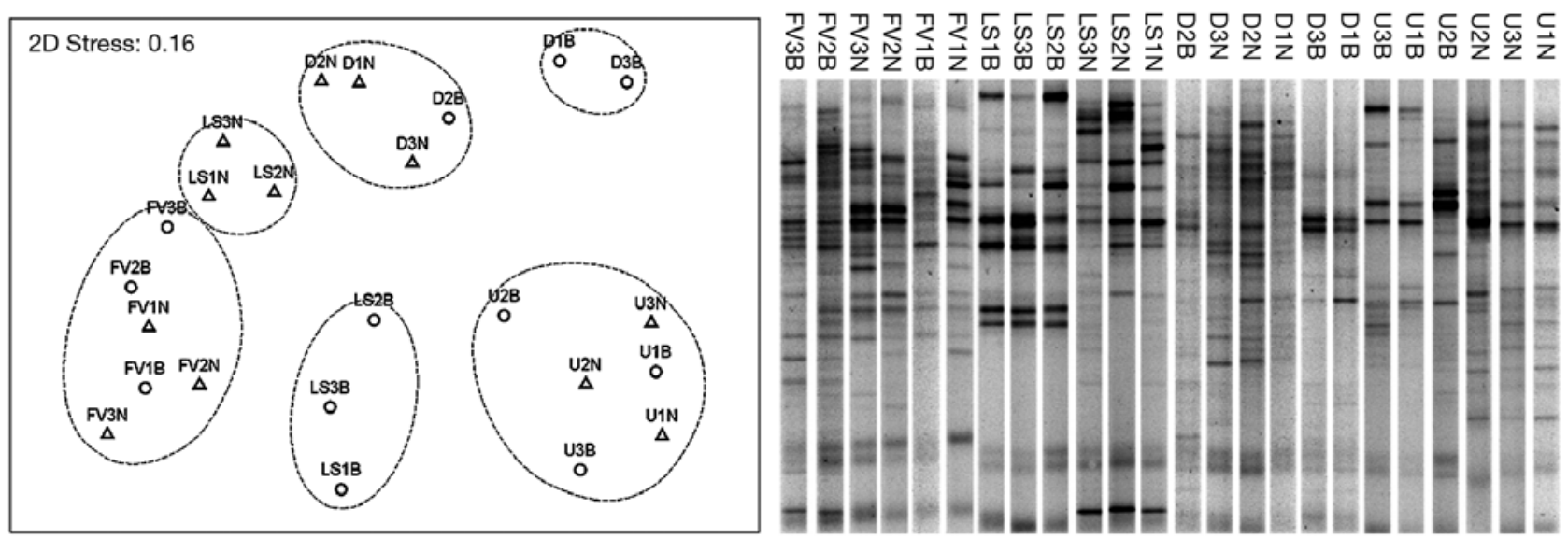

Fig. 3. DGGE gel and non-metric multidimensional scaling (NMDS) plot showing the regional comparison of epibacterial communities of macroalgal species from North $(N, \Delta)$ and Baltic $(B, O)$ Seas. NMDS of DGGE band patterns was performed using the Bray-Curtis similarity index. The stress value was 0.16 . (---): $50 \%$ resemblance level. Species abbreviations are given in Fig. 1 
Table 2. ANOSIM pairwise comparison of epibacterial communities on different macroalgal species from the North and Baltic Seas. FV: Fucus vesiculosus; LS: Laminaria saccharina; U: Ulva compressa; D: Delesseria sanguinea; P: Phycodrys rubens. Each group consists of 6 individual algal samples

\begin{tabular}{|llcccc|}
\hline Groups & R & $\begin{array}{c}\text { Significance } \\
\text { level (\%) }\end{array}$ & \multicolumn{2}{c|}{$\begin{array}{c}\text { Permutations } \\
\text { Possible }\end{array}$} & Actual \\
\hline U, D & 0.919 & 0.2 & 462 & 462 & 1 \\
U, LS & 0.92 & 0.2 & 462 & 462 & 1 \\
U, FV & 1.0 & 0.2 & 462 & 462 & 1 \\
D, LS & 0.622 & 0.2 & 462 & 462 & 1 \\
D, FV & 0.936 & 0.2 & 462 & 462 & 1 \\
LS, FV & 0.796 & 0.2 & 462 & 462 & 1 \\
\hline
\end{tabular}

\section{DISCUSSION}

In the present study, a molecular approach using $16 \mathrm{~S}$ rRNA gene-based DGGE analysis was conducted in order to investigate how the structure of epibacterial communities differed between host species, host phyla and host regional provenance (North and Baltic Seas). In microbial ecology, 16S rRNA gene-based DGGE is widely applied as a method to compare bacterial communities in a variety of habitats including macroalgae (Celussi \& Cataletto 2007). Although the information given by a DGGE band pattern is not as detailed as the information obtained, for instance, by a 16S rRNA gene-based clone library, DGGE is considered today to be a valuable method for the comparison of microbial communities in different or changing environments.

The examined marine algal species belong to the phyla Rhodophyta (Delesseria sanguinea and Phycodrys rubens), Chlorophyta (Ulva compressa) and Phaeophyta (Fucus serratus, F. vesiculosus and Laminaria saccharina). Although a certain inter-individual variability was observed even on conspecific algae (e.g. Ulva in the Baltic Sea), the general factors contributing to the dissimilarity among epibacterial communities were - with increasing importance-region, host species and host phylum. Host specificity of the associated bacterial community has already been described for red algae (Ashen \& Goff 2000), Caribbean corals (Rohwer et al. 2001) and sponges of Australian temperate waters (Taylor et al. 2004). Taylor et al. (2004) analysed bacterial communities of 3 different sponges based on DGGE. They reported a certain variability at all levels, but the highest variation was observed among host species indicating, similarly to the present study, host-specific associations. Surprisingly, in the present study, host specificity was not blurred when algae of very different provenance were pooled. Even though the sampling sites were in the same longitudinal range with similar light regimes and water temperatures, both habitats differ considerably with regard to salinity, tidal range and, most likely, bacterioplankton composition. Pinhassi et al. (2003) investigated the bacterial community composition of the North and Baltic Seas in the Skagerrak-Kattegat Front and found substantial differences on each side of the front. Staufenberger et al. (2008) investigated the bacterial community of the water surrounding L. saccharina individuals in the North and Baltic Seas using 16S rRNA gene-based DGGE analysis and found substantial differences in the bacterial community of the algal thalli from each location. Furthermore, Staufenberger et al. (2008) could detect a specific bacterial community on young thallus parts regardless of the geographic origin or season of sampling. The data from the present study extend the phenomenon of host-specific epibacterial communities to other algal species.

While the composition of epibacterial communities varies within conspecific algae and between regions, this variability is generally lower than the differences between algal species or host phyla. The finding suggests that species-specific properties of the algal surface and/or specific interactions between algae and bacteria may be the driving force for this selectivity.

Although our survey was limited to 6 algal species and only 2 sampling sites in the same temperate region, the results from the present study provide strong support for the hypothesis that the physicochemical properties of macroalgal thalli may determine the differential settlement and growth of bacteria on their surfaces. There are 3 possible processes which, singly or in combination, may produce algalspecific biofilms: (1) algal propagules may already carry the specific biofilm; (2) specific algal defences may selectively inhibit the growth of biofilms other than that specific to the alga, as was demonstrated for Delisea pulchra (Steinberg et al. 1997), or repel already attached agarolytic bacteria (Weinberger et al. 1999); and (3) algal attractants may favour the settlement of certain strains (Pasmore \& Costerton 2003). Besides repellent-attractant activity, algae can also affect bacterial growth (stimulate or inhibit). Additionally, physical properties of algae may allow adhesion of some bacterial strains and suppress attachment of others.

The epibacterial communities may in turn have an impact on further interactions between the host alga and its environment (e.g. larval settlement as reviewed by Dobretsov et al. 2006). Micro- and macrofouling is likely to be influenced by the identity and metabolism of epibiotic bacteria, however, any transcutaneous exchanges (light, nutrients, exudates, signalling molecules and other chemicals) may also be affected by the specific surface-attached bacteria (Wahl 2008). Because epibiotic bacteria are known to metabolize algal exudates and produce their own metabolites, 
chemical signals of the host algae are very likely modified by their biofilms. Interactions with chemically cueing parasites, pathogens or consumers may be modulated by epibacterial biofilms (Harder et al. 2002, Tait et al. 2005, Dworjanyn \& Pirozzi 2008). Thus, an alga's capacity to control composition, and density, of its biofilm is probably everything but trivial. A detailed metagenomic investigation of bacterial communities, as well as a seasonal analysis of the stability of algal associated microorganisms and further investigation of epibacterial communities of macroalgae from different marine habitats (e.g. tropical habitats), should facilitate and improve our understanding of the interaction between macroalgae and bacteria.

\section{LITERATURE CITED}

Ashen JB, Goff LJ (2000) Molecular and ecological evidence for species specificity and coevolution in a group of marine algal-bacterial symbioses. Appl Environ Microbiol 66: 3024-3030

Celussi M, Cataletto B (2007) Annual dynamics of bacterioplankton assemblages in the Gulf of Trieste (Northern Adriatic Sea). Gene 406:113-123

Croft MT, Warren MJ, Smith AG (2006) Algae need their vitamins. Eukaryot Cell 5:1175-1183

Dobretsov SV, Qian PY (2002) Effect of bacteria associated with the green alga Ulva reticulata on marine micro- and macrofouling. Biofouling 18:217-228

Dobretsov S, Dahms HU, Qian PY (2006) Inhibition of biofouling by marine microorganisms and their metabolites. Biofouling 22:43-54

Dworjanyn SA, Pirozzi I (2008) Induction of settlement in the sea urchin Tripneustes gratilla by macroalgae, biofilms and conspecifics: a role for bacteria? Aquaculture 274: $268-274$

> Harder T, Lam C, Qian PY (2002) Induction of larval settlement in the polychaete Hydroides elegans by marine biofilms: an investigation of monospecific diatom films as settlement cues. Mar Ecol Prog Ser 229:105-112

Ivanova EP, Sawabe T, Alexeeva YV, Lysenko AM and others (2002) Pseudoalteromonas issachenkonii sp. nov., a bacterium that degrades the thallus of the brown alga Fucus evanescens. Int J Syst Evol Microbiol 52:229-234

Longford SR, Tujula NA, Crocetti GR, Holmes AJ and others (2007) Comparisons of diversity of bacterial communities associated with three sessile marine eukaryotes. Aquat Microb Ecol 48:217-229

Matsuo Y, Imagawa H, Nishizawa M, Shizuri Y (2005) Isolation of an algal morphogenesis inducer from a marine bacterium. Science 307:1598

Mazure HGF, Field JG (1980) Density and ecological importance of bacteria on kelp fronds in an upwelling region. J Exp Mar Biol Ecol 43:173-182

Michel G, Nyval-Collen P, Barbeyron T, Czjzek M, Helbert W (2006) Bioconversion of red seaweed galactans: a focus on bacterial agarases and carrageenases. Appl Microbiol

Editorial responsibility: Francesco Patti,

Ischia, Italy
Biotechnol 71:23-33

Muyzer G, Dewaal EC, Uitterlinden AG (1993) Profiling of complex microbial populations by denaturing gradient gel electrophoresis analysis of polymerase chain reactionamplified genes coding for 16S rRNA. Appl Environ Microbiol 59:695-700

Pasmore M, Costerton JW (2003) Biofilms, bacterial signaling, and their ties to marine biology. J Ind Microbiol Biotechnol 30:407-413

Petri R, Imhoff JF (2001) Genetic analysis of sea-ice bacterial communities of the Western Baltic Sea using an improved double gradient method. Polar Biol 24:252-257

Pinhassi J, Winding A, Binnerup SJ, Zweifel UL, Riemann B, Hagstrom A (2003) Spatial variability in bacterioplankton community composition at the Skagerrak-Kattegat Front. Mar Ecol Prog Ser 255:1-13

Rohde S, Hiebenthal C, Wahl M, Karez R, Bischof K (2008) Decreased depth distribution of Fucus vesiculosus (Phaeophyceae) in the Western Baltic: effects of light deficiency and epibionts on growth and photosynthesis. Eur J Phycol 43:143-150

Rohwer F, Breitbart M, Jara J, Azam F, Knowlton N (2001) Diversity of bacteria associated with the Caribbean coral Montastraea franksi. Coral Reefs 20:85-91

Staufenberger T, Thiel V, Wiese J, Imhoff JF (2008) Phylogenetic analysis of bacteria associated with Laminaria saccharina. FEMS Microbiol Ecol 64:65-77

Steinberg PD, Schneider R, Kjelleberg S (1997) Chemical defenses of seaweeds against microbial colonization. Biodegradation 8:211-220

Tait K, Joint I, Daykin M, Milton DL, Williams P, Camara M (2005) Disruption of quorum sensing in seawater abolishes attraction of zoospores of the green alga Ulva to bacterial biofilms. Environ Microbiol 7:229-240

Taylor MW, Schupp PJ, Dahllof I, Kjelleberg S, Steinberg PD (2004) Host specificity in marine sponge-associated bacteria, and potential implications for marine microbial diversity. Environ Microbiol 6:121-130

> Tsavkelova EA, Klimova SY, Cherdyntseva TA, Netrusov AI (2006) Microbial producers of plant growth stimulators and their practical use: a review. Appl Biochem Microbiol 42:117-126

> Vairappan CS, Suzuki M, Motomura T, Ichimura T (2001) Pathogenic bacteria associated with lesions and thallus bleaching symptoms in the Japanese kelp Laminaria religiosa Miyabe (Laminariales, Phaeophyceae). Hydrobiologia 445:183-191

- Wahl M (1989) Marine epibiosis. 1. Fouling and antifouling: some basic aspects. Mar Ecol Prog Ser 58:175-189

> Wahl M (2008) Ecological lever and interface ecology: epibiosis modulates the interactions between host and environment. Biofouling 24:427-438

Wahl M, Hay ME (1995) Associational resistance and shared doom: effects of epibiosis on herbivory. Oecologia 102: 329-340

- Weinberger F, Friedlander M, Hoppe HG (1999) Oligoagars elicit a physiological response in Gracilaria conferta (Rhodophyta). J Phycol 35:747-755

Wieczorek SK, Todd CD (1998) Inhibition and facilitation of settlement of epifaunal marine invertebrate larvae by microbial biofilm cues. Biofouling 12:81-118

Submitted: October 31, 2008; Accepted: March 16, 2009

Proofs received from author(s): April 2, 2009 